\title{
ANALISIS DATA INFLASI DI INDONESIA PASCA KENAIKAN TDL DAN BBM TAHUN 2013 MENGGUNAKAN MODEL REGRESI KERNEL
}

\author{
Suparti $^{1}$ \\ ${ }^{1}$ Staf Pengajar Jurusan Statistika Undip \\ e-mail : supartisudargo@yahoo.co.id
}

\begin{abstract}
The inflation data is one of the financial time series data that has a high volatility, so if the data is modeled with parametric models (AR, MA and ARIMA), sometimes occur problems because there was an assumption that cannot be satisfied. Then a nonparametric method that does not require strict assumptions as parametric methods is developed. This study aims to analyze inflation in Indonesia after the goverment raised the price of electricity basic and fuel price in 2013 using kernel regression models. This method was good for data modeling inflation in Indonesia before. The goodness of a kernel regression model is determined by the chosen kernel function and wide bandwidth used. However, the most dominant is the selection of the wide bandwidth. In this study, determination of the optimal bandwidth by minimizing the Generalized Cross Validation (GCV).

By model the annual inflation data (Indonesia) December 2006 - December 2011, the inflation target in 2012 is $(4,5 \pm 1) \%$ can be achieved both exactly and predictly, while the inflation target in 2013 is $(4,5 \pm 1) \%$ cannot be achieved neither exactly nor predictly. The inflation target in 2013 can't be achieve because since the beginning of 2013, there was a government policy to raise the price of electricity and the middle of 2013, there was an increase in fuel prices. The prediction of Indonesia inflation in 2014 by Gauss kernel is 6,18\%.
\end{abstract}

Keywords: Inflation, Kernel Regression Models, Generalized Cross Validation

\section{Pendahuluan}

Inflasi merupakan kecenderungan (trend) atau gerakan naiknya tingkat harga umum yang berlangsung secara terus-menerus dari suatu periode ke periode berikutnya. Inflasi yang terkendali dan rendah dapat mendukung terpeliharanya daya beli masyarakat. Sedangkan inflasi yang tidak stabil akan mempersulit dunia usaha dalam perencanaan kegiatan bisnis, baik dalam kegiatan produksi dan investasi maupun dalam penentuan harga barang dan jasa yang diproduksinya. Oleh karenanya diperlukan prediksi inflasi yang akurat di masa yang akan datang agar para pelaku usaha dapat melakukan perencanaan yang matang dalam melakukan kegiatan bisnisnya. Selain para pelaku usaha, prediksi inflasi juga diperlukan oleh pemerintah dalam menetapkan RAPBN. Demikian juga oleh masyarakat, inflasi dapat digunakan sebagai bahan pertimbangan untuk merencanakan suatu investasi.

Data inflasi merupakan salah satu data finansial yang pada umumnya terjadi pelanggaran asumsi jika data tersebut dimodelkan dengan model klasik yaitu karena adanya suatu kondisi heteroskedastisitas yang disebabkan adanya sifat volatilitas dalam datanya. Oleh karena itu, berkembang model-model nonparametrik yang mengabaikan berbagai asumsi sebagaimana pada model parametrik. Salah satu model nonparametrik yang dapat digunakan untuk memodelkan data adalah model regresi kernel ${ }^{[8]}$.

Menurut Bunyamin dan Danila (2011), model inflasi Indonesia terbaik dengan Box Jenkins menggunakan data inflasi tahunan 1998 - 2008 adalah model AR(2) dengan prediksi inflasi pada tahun 2009 sebesar $10,48 \%^{[1]}$. Ternyata hasil prediksi ini sangat jauh 
dengan data riil inflasi tahun 2009 yang besarnya hanya 2.78\%. Namun setelah dikaji ulang oleh penulis dengan menggunakan data inflasi tahunan bulan Desember 2006 Desember 2011, penulis tidak menemukan model Box Jenkins (baik AR, MA maupun ARIMA) yang sesuai karena dari model Box Jenkins yang diidentifikasi ada beberapa model yang signifikan, akan tetapi setelah diverifikasi residualnya ada asumsi yang tidak terpenuhi yaitu semua model yang teridenfikasi signifikan ternyata independensi residualnya tidak dipenuhi ${ }^{[14]}$. Untuk mendapatkan model Box Jenkins yang signifikan dengan semua asumsi residualnya terpenuhi perlu dilakukan penelitian lebih lanjut.

Masih menggunakan data yang sama yaitu data Desember 2006 - Desember 2011, setelah dilakukan pemodelan dengan regresi kernel menggunakan kernel Gauss dengan optimasi Cross Validasi (CV) sebelum ada kebijakan pemerintah dalam kenaikan Tarif Dasar Listrik sepanjang tahun 2013 dan kenaikan BBM pada pertengahan tahun 2013, hasil prediksi menunjukkan bahwa target inflasi yang telah ditetapkan pemerintah pada tahun 2012 dan 2013 sebesar $(4,5 \pm 1) \%$ dapat tercapai ${ }^{[10]}$. Akan tetapi setelah ada kebijakan pemerintah tersebut, terjadi lonjakan inflasi yang signifikan pada bulan Juli sampai November 2013 yang besarnya jauh di atas target inflasi tahun 2013 (Tabel 1). Ini mengindikasikan bahwa target inflasi Indonesia tahun 2013 sulit dicapai. Hal ini didukung oleh pemodelan inflasi menggunakan regresi Spline dengan fungsi spline truncated yang menghasilkan prediksi inflasi tahun 2013 sebesar 8,55\% ${ }^{[9]}$. Akankan model regresi kernel dengan optimasi GCV yang terbentuk juga menunjukkan bahwa prediksi inflasi tahun 2013 mendukung fakta bahwa target inflasi tahun 2013 juga sulit tercapai? Dan apakah target inflasi yang telah ditetapkan pemerintah pada tahun 2014 sebesar $(4,5 \pm 1) \%$ akan tercapai?

Dalam makalah ini penulis melakukan kajian tentang pemodelan inflasi di Indonesia menggunakan model regresi kernel dengan kernel Gauss dan optimasi GCV serta melakukan analisis inflasi terutama setelah ada kebijakan pemerintah menaikkan TDL dan BBM 2013.

\section{Tinjauan Pustaka}

\subsection{Pengertian dan Indikator Inflasi}

Secara sederhana inflasi diartikan sebagai meningkatnya harga-harga secara umum dan terus menerus. Kenaikan harga dari satu atau dua barang saja tidak dapat disebut inflasi kecuali bila kenaikan itu meluas (atau mengakibatkan kenaikan harga) pada barang lainnya. Kebalikan dari inflasi disebut deflasi ${ }^{[6]}$.

Indikator yang sering digunakan untuk mengukur tingkat inflasi adalah Indeks Harga Konsumen (IHK). Perubahan IHK dari waktu ke waktu menunjukkan pergerakan harga dari paket barang dan jasa yang dikonsumsi masyarakat. Sejak Juli 2008, paket barang dan jasa dalam keranjang IHK telah dilakukan atas dasar Survei Biaya Hidup (SBH) Tahun 2007 yang dilaksanakan oleh Badan Pusat Statistik (BPS). Kemudian, BPS akan memonitor perkembangan harga dari barang dan jasa tersebut secara bulanan di beberapa kota, di pasar tradisional dan modern terhadap beberapa jenis barang/jasa di setiap $\operatorname{kota}^{[5]}$.

\subsection{Penetapan Target Inflasi}

Target atau sasaran inflasi merupakan tingkat inflasi yang harus dicapai oleh Bank Indonesia, berkoordinasi dengan Pemerintah. Penetapan sasaran inflasi berdasarkan UU mengenai Bank Indonesia dilakukan oleh Pemerintah. Sasaran inflasi yang ditetapkan oleh Pemerintah untuk periode 2012 - 2015, masing-masing sebesar 4,5\%, 4,5\%, 4,5\%, dan 4\% masing-masing dengan deviasi $\pm 1 \%{ }^{[4,7]}$. 
Sasaran inflasi tersebut diharapkan dapat menjadi acuan bagi pelaku usaha dan masyarakat dalam melakukan kegiatan ekonominya ke depan sehingga tingkat inflasi dapat diturunkan pada tingkat yang rendah dan stabil. Pemerintah dan Bank Indonesia akan senantiasa berkomitmen untuk mencapai sasaran inflasi yang ditetapkan tersebut melalui koordinasi kebijakan yang konsisten dengan sasaran inflasi tersebut. Salah satu upaya pengendalian inflasi menuju inflasi yang rendah dan stabil adalah dengan membentuk dan mengarahkan ekspektasi inflasi masyarakat agar mengacu pada sasaran inflasi yang telah ditetapkan ${ }^{[4]}$.

\subsection{Model Regresi Nonparametrik}

Model regresi nonparametrik adalah

$$
\mathrm{Y}_{\mathrm{i}}=\mathrm{g}\left(\mathrm{X}_{\mathrm{i}}\right)+\mathrm{e}_{\mathrm{i}} \quad, i=1,2, \ldots, n
$$

dengan $X_{i}$ adalah variabel prediktor, $Y_{i}$ merupakan variabel respon dan $g\left(X_{i}\right)$ merupakan fungsi regresi rataan $E\left[Y_{i} \mid X_{i}\right]$ yang tak diketahui. Sementara $e_{i}$ diasumsikan sebagai kesalahan pengamatan yang merupakan variabel random independen dengan mean 0 dan varian $\sigma^{2}$.

Ada dua versi rancangan titik dari model (1) yakni:

1. Model rancangan tetap/fixed design, dengan $X_{i}$ adalah desain titik non random dengan error observasi berdistribusi independen dan identik yakni normal dengan mean 0 dan varian $\sigma^{2}$.

2. Model rancangan random/random design, dengan $\left(\mathrm{X}_{\mathrm{i}}, \mathrm{Y}_{\mathrm{i}}\right)$ independen dengan $\mathrm{g}(\mathrm{x})=\mathrm{E}(\mathrm{Y} \mid \mathrm{X}=\mathrm{x})$ dan $\mathrm{e}_{\mathrm{i}}=\mathrm{Y}_{\mathrm{i}}-\mathrm{g}\left(\mathrm{X}_{\mathrm{i}}\right)$.

Pendekatan nonparametrik dilakukan jika asumsi bentuk g tidak diketahui. Dalam hal ini, diasumsikan bahwa bentuk g termuat dalam kelas fungsi mulus, artinya mempunyai turunan kontinu atau dapat diintegralkan secara kuadrat.

\subsection{Estimator Regresi Kernel}

Diberikan data pengamatan independen $\left\{\left(\mathrm{X}_{\mathrm{i}}, \mathrm{Y}_{\mathrm{i}}\right)\right\}_{\mathrm{i}=1}^{\mathrm{n}}$ mempunyai model (1). Jika $\left\{\mathrm{W}_{\mathrm{ni}}(\mathrm{x})\right\}$ barisan bobot-bobot positip sehingga $\mathrm{n}^{-1} \sum_{\mathrm{i}=1}^{\mathrm{n}} \mathrm{W}_{\mathrm{ni}}(\mathrm{x})=1$, maka estimator kuadrat terkecil dari $g$ adalah

$$
\hat{\mathrm{g}}(\mathrm{x})=\mathrm{n}^{-1} \sum_{\mathrm{i}=1}^{\mathrm{n}} \mathrm{W}_{\mathrm{ni}}(\mathrm{x}) \mathrm{Y}_{\mathrm{i}} \text {. }
$$

Suatu fungsi $\mathrm{K}($.$) disebut fungsi kernel jika K fungsi kontinu, berharga riil, simetris,$ terbatas dan $\int_{-\infty}^{\infty} K(y) d y=1$. Jika $K$ suatu kernel dengan sifat

1. $\int_{-\infty}^{\infty} \mathrm{x}{ }^{\mathrm{j}} \mathrm{K}(\mathrm{x}) \mathrm{dx}=0$, untuk $j=1,2, \ldots, r-1$

2. $\int_{-\infty}^{\infty} \mathrm{x}^{\mathrm{r}} \mathrm{K}(\mathrm{x}) \mathrm{dx} \neq 0$ atau $\infty$, maka $\mathrm{K}$ disebut kernel order $r$

Beberapa contoh fungsi kernel diantaranya ${ }^{[3]}$ :

1. Seragam (Uniform)

$$
K(x)=\left\{\begin{array}{l}
1 / 2, \text { untuk }|x| \leq 1 \\
0, \quad \text { untuk } x \text { yang lain }
\end{array}\right.
$$




\section{Segitiga}

$$
\mathrm{K}(\mathrm{x})=\left\{\begin{array}{c}
1-|\mathrm{x}| \text {, untuk }|\mathrm{x}| \leq 1 \\
0, \text { untuk } \mathrm{x} \text { yang lain }
\end{array}\right.
$$

3. Epanechnikov

$$
\mathrm{K}(\mathrm{x})=\left\{\begin{array}{cl}
3 / 4\left(1-\mathrm{x}^{2}\right), & \text { untuk }|\mathrm{x}| \leq 1 \\
0, & \text { untuk } \mathrm{x} \text { yang lain }
\end{array}\right.
$$

4. Gauss

$$
\mathrm{K}(\mathrm{x})=\frac{1}{\sqrt{2} \pi} \mathrm{e}^{-\mathrm{x}^{2} / 2}, \text { untuk }|\mathrm{x}|<\infty
$$

Secara umum estimator regresi kernel dari $g$ adalah estimator kuadrat terkecil $\hat{\mathrm{g}}(\mathrm{x})=\mathrm{n}^{-1} \sum_{\mathrm{i}=1}^{\mathrm{n}} \mathrm{W}_{n \mathrm{i}}(\mathrm{x}) \mathrm{Y}_{\mathrm{i}}$, dengan fungsi bobot $\mathrm{W}_{\text {ni }}(\mathrm{x})$ tergantung pada kernel K. Jika densitas X tak diketahui, Hardle (1990) memberikan bobot $\mathrm{W}_{\mathrm{ni}}(\mathrm{x})=\frac{\mathrm{K}_{\mathrm{h}}\left(\mathrm{x}-\mathrm{X}_{\mathrm{i}}\right)}{\hat{\mathrm{f}}_{\mathrm{h}}(\mathrm{x})}$ dengan $\hat{\mathrm{f}}_{\mathrm{h}}(\mathrm{x})=\mathrm{n}^{-1} \sum \mathrm{K}_{\mathrm{h}}\left(\mathrm{x}-\mathrm{X}_{\mathrm{i}}\right)$ dan $\mathrm{K}_{\mathrm{h}}(\mathrm{u})=\mathrm{h}^{-1} \mathrm{~K}\left(\frac{\mathrm{u}}{\mathrm{h}}\right)$, sehingga estimator kernel dari regresi $g$ adalah $\hat{g}_{\mathrm{h}}(\mathrm{x})=\frac{\mathrm{n}^{-1} \sum_{\mathrm{i}=1}^{\mathrm{n}} \mathrm{K}_{\mathrm{h}}\left(\mathrm{x}-\mathrm{X}_{\mathrm{i}}\right) \mathrm{Y}_{\mathrm{i}}}{\mathrm{n}^{-1} \sum_{\mathrm{i}=1}^{\mathrm{n}} \mathrm{K}_{\mathrm{h}}\left(\mathrm{x}-\mathrm{X}_{\mathrm{i}}\right)}$. Selanjutnya, jika densitas variabel $\mathrm{X}$ diketahui, Greblicki (1974) dalam Hardle (1990) memberikan bobot $\mathrm{W}_{\mathrm{ni}}(\mathrm{x})=\mathrm{K}_{\mathrm{h}}\left(\mathrm{x}-\mathrm{X}_{\mathrm{i}}\right) / \mathrm{f}(\mathrm{x})$, sehingga estimator kernel dari regresi $g$ adalah $\hat{g}_{h}(x)=\frac{n^{-1} \sum_{i=1}^{n} K_{h}\left(x-X_{i}\right) Y_{i}}{f(x)}{ }^{[3]}$. $\hat{\mathrm{g}}_{\mathrm{h}}(\mathrm{x})=\frac{\mathrm{n}^{-1} \sum_{\mathrm{i}=1}^{\mathrm{n}} \mathrm{K}_{\mathrm{h}}\left(\mathrm{x}-\mathrm{X}_{\mathrm{i}}\right) \mathrm{Y}_{\mathrm{i}}}{\mathrm{n}^{-1} \sum_{\mathrm{i}=1}^{\mathrm{n}} \mathrm{K}_{\mathrm{h}}\left(\mathrm{x}-\mathrm{X}_{\mathrm{i}}\right)}$ dikenal dengan estimator Nadaraya Watson dan dapat ditulis sebagai $\hat{g}_{\mathrm{h}}(\mathrm{x})=\frac{\sum_{\mathrm{i}=1}^{\mathrm{n}} \mathrm{K}_{\mathrm{h}}\left(\mathrm{x}-\mathrm{X}_{\mathrm{i}}\right) \mathrm{Y}_{\mathrm{i}}}{\sum_{\mathrm{i}=1}^{\mathrm{n}} \mathrm{K}_{\mathrm{h}}\left(\mathrm{x}-\mathrm{X}_{\mathrm{i}}\right)}$, sehingga $\hat{\mathrm{g}}_{\mathrm{h}}\left(\mathrm{X}_{\mathrm{i}}\right)=\frac{\sum_{\mathrm{j}=1}^{\mathrm{n}} \mathrm{K}_{\mathrm{h}}\left(\mathrm{X}_{\mathrm{i}}-\mathrm{X}_{\mathrm{j}}\right) \mathrm{Y}_{\mathrm{j}}}{\sum_{\mathrm{k}=1}^{\mathrm{n}} \mathrm{K}_{\mathrm{h}}\left(\mathrm{X}_{\mathrm{i}}-\mathrm{X}_{\mathrm{k}}\right)}=\sum_{j=1}^{n} h_{i j} Y_{j}$ dengan $\mathrm{h}_{\mathrm{ij}}=\frac{K\left[\frac{\mathrm{X}_{\mathrm{i}}-\mathrm{X}_{\mathrm{j}}}{h}\right]}{\sum_{\mathrm{k}=1}^{\mathrm{n}} K\left[\frac{\mathrm{X}_{\mathrm{i}}-\mathrm{X}_{\mathrm{k}}}{h}\right]}$

Keefektifan fungsi bobot $\mathrm{W}_{\mathrm{ni}}(\mathrm{x})$ dari penghalus kernel dibentuk oleh kernel $\mathrm{K}$ dan barisan bandwidth $h$, oleh karena itu untuk selanjutnya $\mathrm{W}_{\mathrm{ni}}(\mathrm{x})$ disimbolkan dengan 
$\mathrm{W}_{\mathrm{hi}}(\mathrm{x})$. Ketepatan estimasi kurva regresi $\hat{\mathrm{g}}_{\mathrm{h}}(\mathrm{x})$ bukan hanya bergantung pada bandwidth $h$ saja, tetapi bergantung dari pasangan $(\mathrm{K}, h)$. Namun pemilihan kernel $\mathrm{K}$ tidak memberikan pengaruh besar seperti halnya nilai bandwidth h nya. Pemilihan bandwidth $h$ yang terlalu besar akan memberikan kurva estimasi yang over smooth sedangkan pemilihan $h$ yang terlalu kecil akan memberikan kurva estimasi yang under smooth. Oleh karena itu perlu dipilih nilai $h$ yang optimal untuk mendapatkan kurva estimasi yang optimal. Beberapa metode optimasi untuk mendapatkan $\mathrm{h}$ optimal adalah metode optimasi MSE (Mean Squared Error), CV (Cross Validation) dan GCV(Generalized Cross

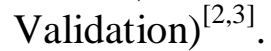

Metode optimasi MSE adalah memilih nilai $h$ optimal yang meminimalkan nilai MSE dengan $\operatorname{MSE}(\mathrm{h})=\mathrm{n}^{-1} \sum_{\mathrm{i}=1}^{\mathrm{n}}\left[\mathrm{Y}_{\mathrm{i}}-\hat{\mathrm{g}}_{\mathrm{h}}\left(\mathrm{X}_{\mathrm{i}}\right)\right]^{2}$. Sedangkan metode optimasi CV adalah memilih nilai $h$ optimal yang meminimalkan nilai CV. Bila estimasi kurva regresi menggunakan sebanyak $n-1$ data (mengeluarkan satu data/leave one-out), nilai $\mathrm{CV}$ diperoleh dengan mengganti $\hat{\mathrm{g}}_{\mathrm{h}}\left(\mathrm{X}_{\mathrm{i}}\right)$ dengan $\hat{\mathrm{g}}_{\mathrm{h}, \mathrm{i}}\left(\mathrm{X}_{\mathrm{i}}\right)$ pada rumus $\operatorname{MSE}(h)$ yang mana $\hat{\mathrm{g}}_{\mathrm{h}, \mathrm{i}}\left(\mathrm{X}_{\mathrm{i}}\right)$ merupakan estimasi leave one-out berdasarkan pada penghalusan regresi dengan menghilangkan salah satu pengamatan yaitu pengamatan ke- $i$, yaitu $\hat{\mathrm{g}}_{\mathrm{h}, \mathrm{i}}\left(\mathrm{X}_{\mathrm{i}}\right)=\mathrm{n}^{-1} \sum_{\mathrm{j}=1, \mathrm{j} \neq \mathrm{i}}^{\mathrm{n}} \mathrm{W}_{\mathrm{hj}}\left(\mathrm{X}_{\mathrm{i}}\right) \mathrm{Y}_{\mathrm{j}}$.

Dengan modifikasi penghalusan tersebut maka terbentuk fungsi cross validasi yakni:

$$
\begin{aligned}
& \mathrm{CV}(\mathrm{h})=\mathrm{n}^{-1} \sum_{\mathrm{i}=1}^{\mathrm{n}}\left[\mathrm{Y}_{\mathrm{i}}-\hat{\mathrm{g}}_{\mathrm{h}, \mathrm{i}}\left(\mathrm{X}_{\mathrm{i}}\right)\right]^{2}=n^{-1} \sum_{i=1}^{n}\left[\frac{\mathrm{Y}_{\mathrm{i}}-\hat{\mathrm{g}}_{\mathrm{h}}\left(\mathrm{X}_{\mathrm{i}}\right)}{1-\mathrm{h}_{\mathrm{ii}}}\right]^{2} \\
& \text { dengan } \mathrm{h}_{\mathrm{ii}}=\frac{K[0]}{\sum_{\mathrm{k}=1}^{\mathrm{n}} K\left[\frac{\mathrm{X}_{\mathrm{i}}-\mathrm{X}_{\mathrm{k}}}{h}\right]} .
\end{aligned}
$$

Perbedaan antara CV dan MSE terletak pada nilai $\hat{\mathrm{g}}_{\mathrm{h}, \mathrm{i}}\left(\mathrm{X}_{\mathrm{i}}\right)$ pada CV dihitung dari (n-1) data sedangkan nilai $\hat{g}_{\mathrm{h}}\left(\mathrm{X}_{\mathrm{i}}\right)$ pada MSE dihitung menggunakan $\mathrm{n}$ data. Sedangkan optimasi GCV adalah memilih h optimal yang meminimalkan nilai GCV dengan nilai GCV diperoleh dari nilai CV dengan mengganti $h_{i i}$ dengan $\frac{\sum_{i=1}^{n} h_{i i}}{n}$, sehingga rumus $\operatorname{GCV}(\mathrm{h})=\frac{n^{-1} \sum_{\mathrm{i}=1}^{\mathrm{n}}\left[\mathrm{Y}_{\mathrm{i}}-\hat{\mathrm{g}}_{\mathrm{h}}\left(\mathrm{X}_{\mathrm{i}}\right)\right]^{2}}{\left[1-\frac{\sum_{\mathrm{i}=1}^{\mathrm{n}} \mathrm{h}_{\mathrm{ii}}}{\mathrm{n}}\right]^{2}}$.

\subsection{Pemodelan Data Runtun Waktu dengan metode kernel}

Pada dasarnya $\left(\mathrm{X}_{\mathrm{i}}, \mathrm{Y}_{\mathrm{i}}\right), i=1,2, \ldots, n$ dalam pemodelan regresi adalah saling independen. Namun dalam prakteknya sering dijumpai bahwa asumsi independensi data tersebut tidak dipenuhi misalnya dalam kasus pengamatan data yang telah dicatat dalam urutan waktu dari suatu obyek penelitian yang mana respon obyek sekarang tergantung 
dari respon sebelumnya. Oleh karena itu perlu disusun suatu pemodelan data yang asumsi independensi datanya tidak dipenuhi. Ada 3 konsep dasar matematika yang mendasarari pemodelan ini ${ }^{[3]}$, yaitu:

1. Model (S) : Suatu barisan stasioner $\left\{\left(\mathrm{X}_{\mathrm{i}}, \mathrm{Y}_{\mathrm{i}}\right), i=2,3, \ldots, n\right\}$ (boleh dependen stokastik) telah diobservasi dan akan diestimasi $\mathrm{g}(\mathrm{x})=\mathrm{E}(\mathrm{Y} \mid \mathrm{X}=\mathrm{x})$

2. Model (T) : Suatu runtun waktu $\left\{Z_{i}, i \geq 1\right\}$ telah diobservasi dan akan diprediksi $Z_{n+1}$ dengan $g(x)=E\left(Z_{n+1} \mid Z_{n}=x\right)$.

3. Model $(\mathrm{C})$ : Error observasi $\left\{\mathrm{e}_{\text {in }}\right\}$ dalam model regresi dengan rancangan tetap $\mathrm{Y}_{\text {in }}=\mathrm{g}(\mathrm{i} / \mathrm{n})+\mathrm{e}_{\text {in }}$, membentuk barisan variabel random yang berkorelasi.

Menurut Hardle (1990), permasalahan model (T) dapat dipetakan dengan permasalahan dalam model $(\mathrm{S})$ dengan mendefinisikan dalam runtun waktu $\left\{\mathrm{Z}_{\mathrm{i}}, i \geq 1\right\}$, nilai lag $\mathrm{Z}_{\mathrm{i}-1}$ sebagai $\mathrm{X}_{\mathrm{i}}$ dan nilai $\mathrm{Z}_{\mathrm{i}}$ sebagai $\mathrm{Y}_{\mathrm{i}}$. Selanjutnya masalah prediksi $\mathrm{Z}_{\mathrm{n}+1}$ dari $\left\{\mathrm{Z}_{\mathrm{i}}\right\}, i=1,2, \ldots, n$ dapat dipandang sebagai masalah pemulusan regresi untuk $\left\{\left(\mathrm{X}_{\mathrm{i}}, \mathrm{Y}_{\mathrm{i}}\right), \mathrm{i}=2,3, \ldots \mathrm{n}\right\}=\left\{\left(\mathrm{Z}_{\mathrm{i}-1}, \mathrm{Z}_{\mathrm{i}}\right)\right.$, $i=2,3, \ldots n\}^{[3]}$. Jadi masalah prediksi $\left\{\mathrm{Z}_{\mathrm{i}}\right\}$ ekivalen dengan mengestimasi $\mathrm{g}(\mathrm{x})=\mathrm{E}(\mathrm{Y} \mid \mathrm{X}=\mathrm{x})$ untuk runtun waktu dua dimensi $\left\{\left(\mathrm{X}_{\mathrm{i}}, \mathrm{Y}_{\mathrm{i}}\right), i=2,3, \ldots n\right\}$. Selanjutnya fungsi $g$ diestimasi dengan metode kernel.

\section{Metode Penelitian}

Data yang digunakan adalah data inflasi Indonesia tahunan mulai Desember 2006 - Desember 2011 yang diambil dari situs resmi Bank Indonesia ${ }^{[5]}$. Pada dasarnya data inflasi ini merupakan data runtun waktu yang akan dianalisis menggunakan pemodelan regresi kernel dengan bantuan software R. Karena data inflasi $\left\{Z_{i}, i=1,2, \ldots, 61\right\}$ merupakan data runtun waktu, maka untuk memodelkan data inflasi menggunakan regresi kernel, data tersebut diubah menjadi data $\left\{\left(\mathrm{X}_{\mathrm{i}}, \mathrm{Y}_{\mathrm{i}}\right), i=2,3, \ldots n\right\}=\left\{\left(\mathrm{Z}_{\mathrm{i}-1}, \mathrm{Z}_{\mathrm{i}}\right), i=2,3, \ldots n\right\}$ dengan $n=61$. Jadi masalah prediksi $\left\{\mathrm{Z}_{\mathrm{i}}\right\}$ sama dengan mengestimasi $\mathrm{g}(\mathrm{x})=\mathrm{E}(\mathrm{Y} \mid \mathrm{X}=\mathrm{x})$ untuk runtun waktu dua dimensi $\left\{\left(\mathrm{X}_{\mathrm{i}}, \mathrm{Y}_{\mathrm{i}}\right), i=1,2, \ldots, 61\right\}$. Selanjutnya fungsi g diestimasi dengan metode kernel. Dalam penelitian ini digunakan fungsi kernel Gauss karena distribusi Gauss besar perannya dalam statistik dan domainnya meliputi seluruh bilangan riil. Sedangkan pemilihan model optimalnya menggunakan kriteria GCV minimum.

\section{Hasil dan Pembahasan}

Data inflasi yang digunakan adalah data inflasi tahunan pada bulan Desember 2006 Desember 2011 yang digambarkan dalam grafik berikut: 


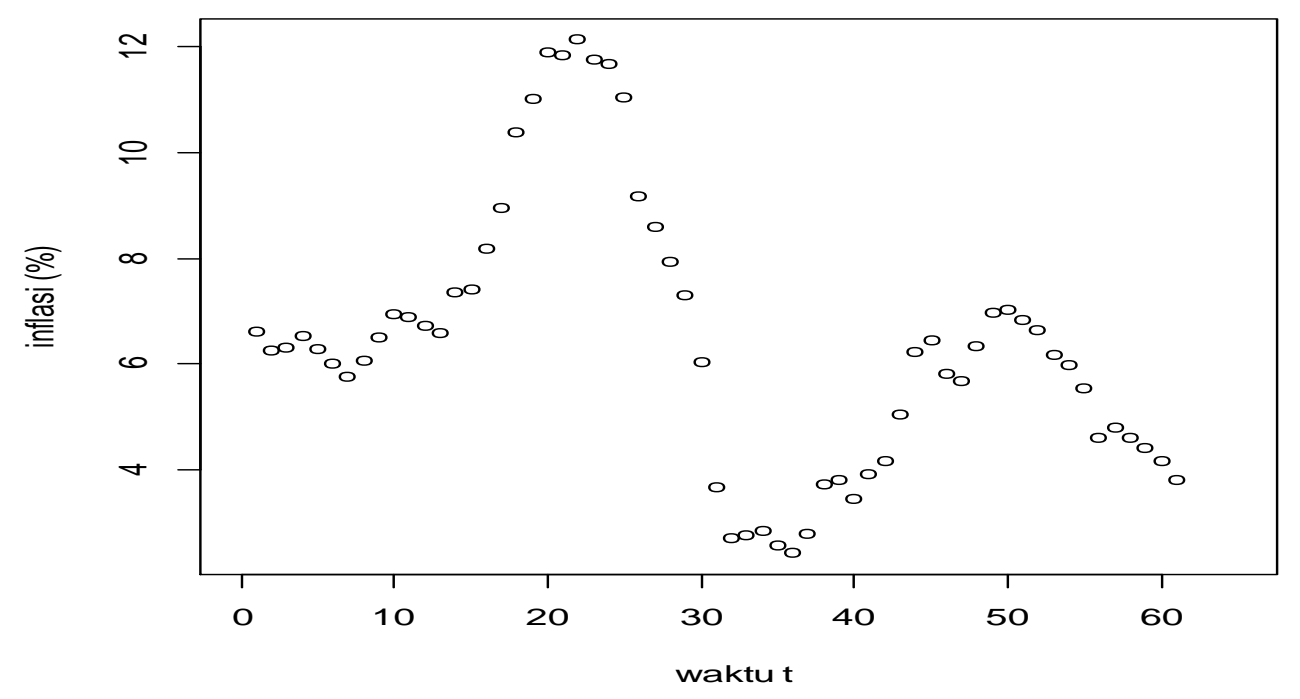

Gambar 1. Data Inflasi Desember 2006 - Desember 2011

Data tersebut diolah dengan program $\mathrm{R}$ menggunakan model regresi kernel dan fungsi kernel yang digunakan adalah fungsi kernel Gauss dengan meminimumkan Generalized Cross Validasi (GCV). GCV minimum sebesar 0.5723039 dicapai pada bandwidth $h$ optimal sebesar 0,59. Perbandingan data inflasi aktual dan prediksi inflasi prediksi disajikan dalam Gambar 2.

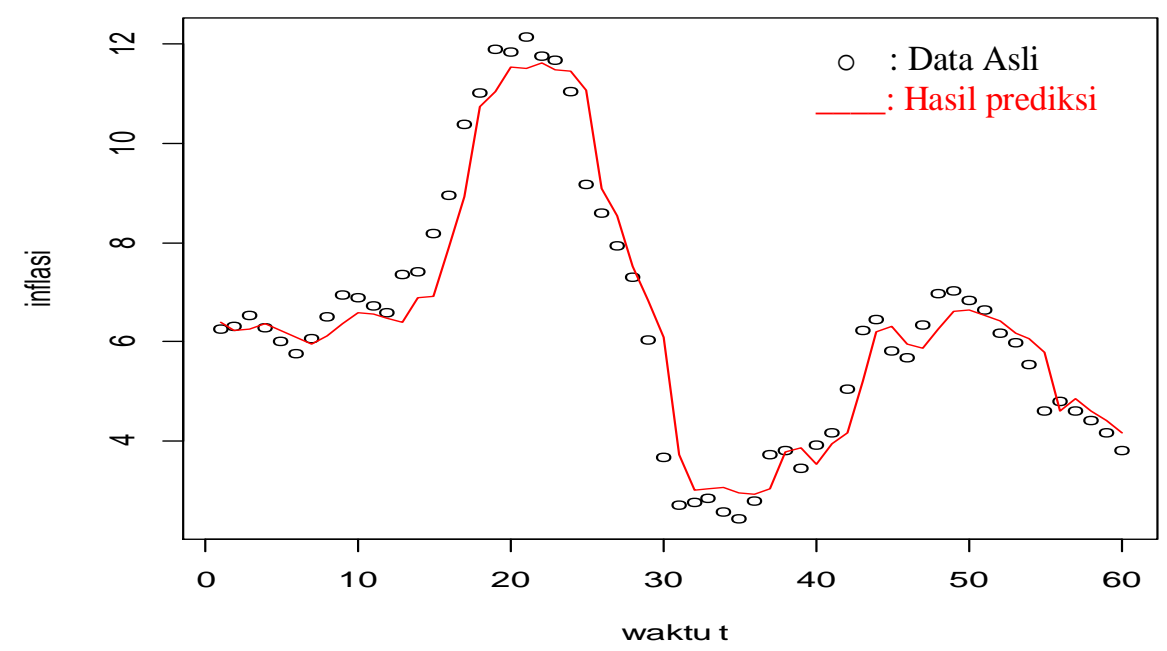

Gambar 2. Grafik Data Inflasi Januari 2007 - Desember 2011 dan Prediksinya

Dengan menggunakan pemodelan regresi kernel menggunakan fungsi kernel Gauss dengan metode optimasi GCV, diperoleh hasil prediksi pada tahun 2012 dan 2013 sebagai berikut: 
Tabel 1. Perbandingan Inflasi Aktual dan Prediksi Inflasi Tahun 2012 -2013

\begin{tabular}{|l|c|c|l|c|c|}
\hline \multicolumn{1}{|c|}{ Bulan } & $\begin{array}{c}\text { Inflasi } \\
\text { Aktual }\end{array}$ & $\begin{array}{c}\text { Inflasi } \\
\text { Prediksi }\end{array}$ & \multicolumn{1}{c|}{ Bulan } & $\begin{array}{c}\text { Inflasi } \\
\text { Aktual }\end{array}$ & $\begin{array}{c}\text { Inflasi } \\
\text { Prediksi }\end{array}$ \\
\hline Januari 2012 & 3,65 & 3,839502 & Januari 2013 & 4,57 & 4,286225 \\
\hline Februari 2012 & 3,56 & 3,716389 & Februari 2013 & 5,31 & 4,565870 \\
\hline Maret 2012 & 3,97 & 3,635648 & Maret 2013 & 5,90 & 5,547663 \\
\hline April 2012 & 4,50 & 3,994226 & April 2013 & 5,57 & 6,020776 \\
\hline Mei 2012 & 4,45 & 4,487741 & Mei 2013 & 5,47 & 5,815532 \\
\hline Juni 2012 & 4,53 & 4,434584 & Juni 2013 & 5,90 & 5,712207 \\
\hline Juli 2012 & 4,56 & 4,520674 & Juli 2013 & 8,61 & 6,020776 \\
\hline Agustus 2012 & 4,58 & 4,554430 & Agustus 2013 & 8,79 & 8,564150 \\
\hline September 2012 & 4,31 & 4,577406 & September 2013 & 8,40 & 8,760669 \\
\hline Oktober 2012 & 4,61 & 4,295675 & Oktober 2013 & 8,32 & 8,279115 \\
\hline November 2012 & 4,32 & 4,612595 & November 2013 & 8,37 & 8,156344 \\
\hline Desember 2012 & 4,30 & 4,305180 & Desember 2013 & & 8,233839 \\
\hline
\end{tabular}

Data inflasi aktual dan hasil prediksinya pada bulan Januari 2012 - Januari 2013 mengalami sedikit naik turun namun tidak signifikan dan hasil prediksinya masih dekat dengan inflasi aktual. Sedangkan data inflasi aktual pada bulan Februari - Juni 2013 mengalami sedikit kenaikan dan pada bulan Juli - Desember 2013 mengalami kenaikan yang lebih besar dibandingkan kenaikan sebelumnya. Hal ini mengindikasikan bahwa kenaikan TDL pada bulan Januari 2013 menyebabkan sedikit kenaikan inflasi pada bulan Februari - Juni 2013, sedangkan kenaikan BBM pada bulan Juni 2013 menyebabkan kenaikan inflasi yang cukup besar dibandingkan kenaikan sebelumnya. Pada hasil prediksi bulan Maret Desember 2013 terlihat ada kenaikan yang cukup signifikan terutama sejak bulan Agustus 2013. Hal ini dikarenakan inflasi aktual mulai Februari 2013 - Juni 2013 cenderung ada kenaikan akibat adanya kenaikan tarif dasar listrik (TDL) sejak bulan Januari 2013. Namun kenaikan inflasi bulan Februari - Juni 2013 tidak sebesar kenaikan pada bulan Juli Desember 2013 yang diakibatkan adanya kenaikan BBM bulan Juni 2013. Kebijakan Pemerintah menaikkan harga BBM berimbas pada kenaikan angka inflasi di Indonesia yang cenderung jauh lebih tinggi dari pada kenaikan inflasi yang dikarenakan kebijakan Pemerintah menaikkan tarif dasar listrik. Gambar 3 berikut ini merupakan perbandingan nilai inflasi aktual dan prediksinya mulai Januari 2007 - Desember 2013.

Dari data aktual pada tahun 2012 menunjukkan bahwa target inflasi pada tahun 2012 sebesar $(4,5 \pm 1) \%$ dapat tercapai. Demikian juga dari hasil prediksi tahun 2012 target tsb dapat tercapai. Sedangkan dari data aktual dan hasil prediksi tahun 2013 menunjukkan bahwa target inflasi sebesar $(4,5 \pm 1) \%$ tidak dapat tercapai. Demikian juga, dari hasil prediksi tahun 2014 diperkirakan target inflasi tahun 2014 sebesar $(4,5 \pm 1) \%$ sulit untuk dicapai. Prediksi inflasi sepanjang tahun 2014 mulai bulan Januari - Desember 2014 berturut-turut sebesar 8,249\%; 8,043\%; 7,705\%; 7,219\%; 6,769\%; 6,493\%; 6,344\%; 6,264\%; $6,222 \% ; 6,199 \% ; 6,187 \% ; 6,180 \%$. Berikut grafik prediksi inflasi pada bulan Januari Desember tahun 2014. 


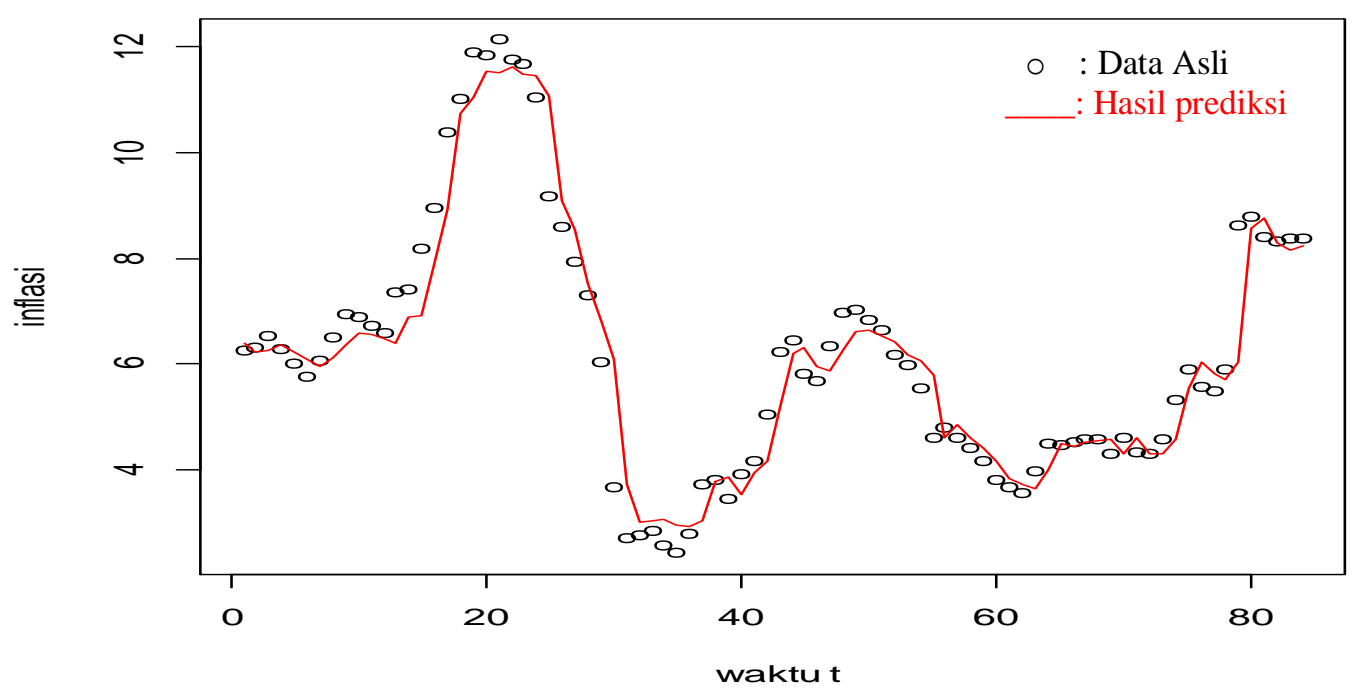

Gambar 3. Grafik Data Inflasi Januari 2007 - Desember 2013 dan Prediksinya

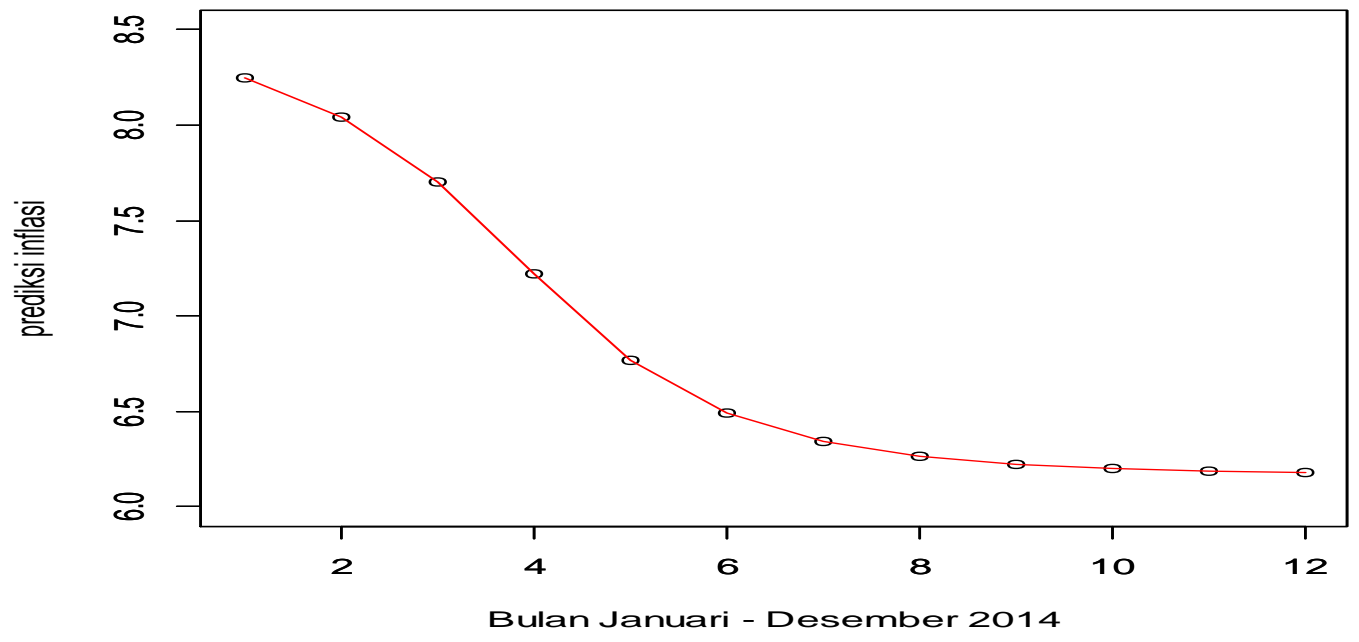

Gambar 4. Grafik Prediksi Inflasi Januari - Desember 2014

\section{Kesimpulan}

Berdasarkan pemodelan data inflasi aktual bulan Desember 2006 - Desember 2011, hasil prediksi inflasi bulan Januari 2012 - Desember 2014 menunjukkan bahwa target inflasi tahun 2012 dapat tercapai sedangkan target inflasi tahun 2013 tidak tercapai dan target inflasi tahun 2014 sulit untuk dicapai. Tidak tercapainya target inflasi tahun 2013 dan 2014 dikarenakan sejak awal tahun 2013 ada kebijakan pemerintah untuk menaikan harga tarif dasar listrik (TDL) dan pertengahan tahun 2013 ada kenaikan harga BBM.

\section{DAFTAR PUSTAKA}

1. Bunyamin dan Danila ,N., Estimasi Inflasi di Indonesia Dengan Menggunakan Metodologi Box Jenkins. National Journals, 2011, Vol. 18, No. 2.

2. Eubank, R. L., Nonparametric Regression and Spline Smoothing , Marcel Dekker, Inc., New York, 1999. 
3. Hardle, W., Applied Nonparametric Regression, Cambridge University Press., New York, 1990.

4. http://www.bi.go.id/id/moneter/inflasi/bi-dan-inflasi/Contents/Penetapan.aspx

5. http://www.bi.go.id/id/moneter/inflasi/data/Default.aspx

6. http://www.bi.go.id/id/moneter/inflasi/pengenalan/Contents/Default.aspx

7. PMK No.66/PMK.011/2012 tanggal 30 April 2012

8. Suparti, Estimasi Regresi Non Parametrik Menggunakan Metode Kernel pada Model rancangan Tetap, Prosiding Seminar Nasional UNNES, 2005, ISBN : 979.9579.80.5.

9. Suparti, Analisis Data Inflasi Di Indonesia Menggunakan Model Regresi Spline, Jurnal Media Statistika, 2013, Vol. 6, No.1.

10. Suparti, Safitri, D., Puspitasari,I. dan Devi, A.R., Analisis Data Inflasi Indonesia Menggunakan Model Regresi Kernel, Prosiding Seminar Nasional Statistika Undip, 2013. 